\title{
KESIAPAN ADOPSI BUILDING INFORMATION MODELING (BIM) PADA KONSULTAN PERENCANA DI KOTA PALEMBANG
}

\author{
Heni Fitriani ${ }^{1)}$, Wina Prasetio Br Bangun ${ }^{2)}$ \\ ${ }^{1,2)}$ Jurusan Teknik Sipil, Fakultas Teknik, Universitas Sriwijaya, Palembang \\ Email: heni.fitriani@unsri.ac.id ${ }^{1)}$, winaprasetio88@gmail.com ${ }^{2)}$
}

DOI: http://dx.doi.org/10.29103/tj.v11i2.568

(Received: July 2021 / Revised: August 2021 / Accepted: August 2021)

\begin{abstract}
Abstrak
Salah satu industri yang memfokuskan pada pengembangan infrastruktur adalah industri Architecture Engineering and Construction (AEC). Penggunaan berbagai teknologi dan aplikasi Building Information Modeling (BIM) pada sektor konstruksi semakin meningkat. Penelitian ini bertujuan untuk mengetahui tingkat kesiapan pelaku AEC khususnya konsultan perencana dalam proses adopsi BIM. Penelitian ini menggunakan survei kuesioner dengan mengumpulkan data dari 96 responden pada perusahaan konsultan di Palembang. Dari hasil analisa didapat bahwa hampir semua responden telah mengetahui istilah BIM dan tingkat kesiapan dalam mengadopsi BIM dengan nilai rata-rata sebesar 3,187 yang berarti bahwa kesiapan konsultan perencana di Kota Palembang dinyatakan cukup siap dalam mengadopsi BIM. Adapun 3 hambatan utama dalam mengadopsi BIM menurut penelitian ini yaitu tingginya biaya investasi awal; terlalu nyaman dengan budaya kerja lama; dan kurangnya pengetahuan mendalam terkait BIM, oleh karena itu penggunaan BIM pada industri konstruksi harus ditingkatkan dengan penguatan regulasi oleh pemerintah. Peranan kesadaran perusahaan dan individu di dalamnya serta ketegasan pemerintah akan menentukan tingkat perkembangan BIM.
\end{abstract}

Kata kunci: Adopsi, digitalisasi, Building Information Modeling, AEC

\begin{abstract}
One of the industries focusing on infrastructure development is Architecture Engineering and Construction (AEC) industry. The use of technology and Building Information Modeling (BIM) in construction sector has been widely increased. This research aimed to identify the readiness level of design consultants on BIM adoption. This research used a questionnaire survey to collect data from 96 respondents of consultant firms in Palembang. Based on the analysis, it was found that almost all respondents were already familiar with BIM term and the level of readiness in adopting BIM had a mean average value of 3.187 , indicating that the respondents were quite ready in adopting BIM. The three main barriers in adopting werethe high investment cost; being too comfortable with the conventional work culture; and lack of knowledge about BIM. Therefore, the use of BIM in the construction industry must be increased by strengthening regulations conducted by the government. The role of corporate, individual awareness and government involvement will determine the level of BIM development.
\end{abstract}

Keywords: Adoption, digitalization, Building Information Modeling, AEC 


\section{Latar Belakang}

Sektor Architecture, Engineering, and Construction (AEC) memiliki konstribusi besar dalam perkembangan industri di Indonesia. Sektor AEC berkontribusi sekitar 11,26\% terhadap Gross Domestic Product (GDP) Indonesia (BPS, 2019). Indonesia menjadi pasar konstruksi terbesar se-Asia Tenggara dan memiliki sokongan dana dari pemerintah yang cukup besar, yaitu sebesar USD 450 Miliar hingga tahun 2022 (LPJK, 2015).

Peningkatan teknologi bidang konstruksi yang pesat di era industri 4.0 membuat pelaku AEC di Indonesia harus mengikuti perkembangan tersebut untuk peningkatan produktivitas kerja. Adapun regulasi yang ditawarkan pemerintah untuk mengikuti era digitalisasi tersebut adalah penggunaan berbagai teknologi dan aplikasi Building Information Modeling (BIM). BIM dan perkembangan dunia konstruksi memiliki hubungan erat dan mendapat banyak perhatian dari banyak pihak di berbagai negara di dunia (Wang, 2012).

BIM merupakan seperangkat teknologi dalam bentuk pemodelan digital bidang konstruksi yang terintegrasi dan terkoordinasi antar bidang pekerjaan (Juan, Lai and Shih, 2017). BIM telah banyak diaplikasikan di berbagai negara di dunia. Amerika Serikat telah mengaplikasikan BIM pada bidang konstruksi sejak 1996 dan pengaplikasian BIM telah digunakan sebesar 50\% dari seluruh pembangunan konstruksi pada tahun 2009 (Wong, Wong and Nadeem, 2010). Untuk wilayah Eropa (Smith, 2014), implementasi BIM dipimpin oleh wilayah Skandinavia (Norwegia, Denmark, Firlandia), sedangkan Singapura memimpin tingkat penggunaan BIM di wilayah Asia dengan level penggunaan sebesar 80\% (Liao and Teo, 2019).

Dibandingkan dengan negara-negara di Asia Tenggara, perkembangan BIM di Indonesia masih sangat lambat (Utomo and Rohman, 2019). Tingkat penggunaan BIM di Indonesia cenderung masih rendah dan level BIM yang digunakan juga masih berada pada tingkatan berbatas pada 3D saja (Mieslenna and Wibowo, 2019). Tingkat implementasi ini jika dibandingkan dengan Malaysia masih terbatas dan mengalami banyak hambatan (Latiffi, Brahim and Fathi, 2016). Cara terbaik untuk meningkatkan implementasi BIM adalah memberi pemahaman dan sugesti kepada pelaku konstruksi tentang potensi dan manfaat BIM (Khosrowshahi and Arayici, 2012). Permasalahan lainnya berkaitan dengan biaya peralihan dan kesediaan perangkat teknologi (Juan, Lai and Shih, 2017) dan juga permasalahan biaya yang dapat diselesaikan dengan penyesuaian implementasi BIM terhadap dunia bisnis agar permasalahan dana pada investasi awal dapat teratasi (Dahlberg, 2016). Penggunaan BIM di Indonesia masih terbatas pada perusahaan besar saja dan memiliki keterbatasan pada tingkat koordinasi (Telaga, 2018). Umumnya pelaku AEC masih mengeluhkan investasi biaya awal yang tinggi dalam mengadopsi BIM serta ketidaknyamanan dalam mengubah budaya kerja konvensional menjadi berbasis BIM. Pelaku konstruksi di Indonesia menganggap BIM sebagai alat bantu semata. Sementara di Inggris BIM digunakan pemerintah sebagai strategi pengembangan konstruksi berkelanjutan (Alwan, Jones and Holgate, 2017).

Penggunaan BIM di Indonesia telah diatur pemerintah melalui Permen PUPR No. 22/PRT/M/2018 Pasal 13 mengenai kewajiban penggunaan BIM pada bangunan negara kriteria tidak sederhana dengan luas diatas $2000 \mathrm{~m}^{2}$ dengan jumlah di atas 2 lantai untuk bangunan berjenis gedung bertingkat (PUPR, 2018). Kewajiban penggunaan BIM di Indonesia masih terbatas dan sumber daya manusia 
yang belum memiliki kemampuan yang cukup menjadi tantangan tersendiri dalam pengadopsian BIM. Tingkat pengaplikasian BIM di Indonesia sendiri masih relatif minim dan membutuhkan perhatian yang lebih mendalam (Hatmoko et al., 2019). Terdapat tiga faktor terbesar yang menghambat adopsi BIM di Indonesia (Utomo and Rohman, 2019) yaitu: 1) Minimnya expert BIM di Indonesia, 2) Minim pengetahuan mengenai manfaat BIM, dan 3) Kebiasaan kerja. Hambatan implementasi BIM umumnya disebabkan oleh koordinasi dan kesadaran diri (Agirachman, Putra and Angkawijaya, 2018).

Penggunaan BIM pada bidang AEC banyak digunakan pada bagian perencanaan dan desain. Konsultan perencana merupakan peranan penting yang menentukan tingkat keberhasilan suatu proyek bangunan dan memberi pengaruh dalam pengambilan keputusan dalam proyek tersebut (Simanjuntak and Herriza, 2019). Besarnya peranan konsultan perencana dalam menentukan tingkat keberhasilan suatu proyek membuat kesiapan konsultan perencana dalam proses adopsi BIM perlu dikaji lebih jauh untuk mengetahui berbagai permasalahan dan hambatan adopsi BIM dari sudut pandang konsultan perencana Indonesia khususnya di Palembang

Penelitian ini bertujuan mengetahui kesiapan konsultan perencana di Palembang dalam mengadopsi BIM. Tingkat kesiapan ini berkaitan dengan level pengetahuan mengenai BIM serta kesiapan dalam menghadapi berbagai hambatan dalam adopsi BIM yang telah dirangkum berdasarkan berbagai sumber dan penelitian sebelumnya. Tujuan lainnya adalah untuk mengetahui hambatan utama dalam mengadopsi BIM di Kota Palembang dan mengetahui potensi perkembangan BIM di Palembang berdasarkan jawaban dari responden. Penelitian ini terbatas kepada konsultan perencana di Palembang dan distribusi kuesioner penelitian dilakukan secara online karena bersifat lebih praktis dan dikarenakan penelitian dilakukan di masa pandemi.

\section{Metode Penelitian}

Penelitian diawali dengan mencari literatur dari berbagai sumber untuk dijadikan referensi terhadap masalah yang ada. Kemudian diikuti dengan penyusunan kuesioner sebagai alat ukur persepsi responden terhadap variabel. Dalam penelitian ini digunakan metode deskriptif dan kuantitatif guna dapat menjelaskan tingkat kesiapan konsultan perencana dalam adopsi BIM. Pernyataan kuesioner disusun berdasarkan literatur-literatur yang ada, selanjutnya disusun ke dalam Google Formulir dan disebar ke perusahaan konsultan perencana di Kota Palembang. Skala likert digunakan pada pertanyaan kuesioner dengan 5 skala yaitu 1-5 di mana 1 menyatakan sangat tidak setuju dan 5 menyatakan sangat setuju seperti terlihat pada Tabel 1 berikut.

Tabel 1 Skala likert

\begin{tabular}{lc}
\hline Keterangan & Skor \\
\hline Sangat tidak setuju/ Tidak berpengaruh & 1 \\
\hline Tidak setuju/ Kurang berpengaruh & 2 \\
\hline Netral/ Cukup berpengaruh & 3 \\
\hline Setuju/ Berpengaruh & 4 \\
\hline Sangat setuju/ Sangat berpengaruh & 5 \\
\hline
\end{tabular}


Pertanyaan disusun berdasarkan variabel yang telah dirangkum berdasarkan berbagai studi literatur dan penelitian terdahulu. Adapun variabel penelitian dapat dilihat pada Tabel 2.

Tabel 2 Variabel penelitian

\begin{tabular}{ll}
\hline \multicolumn{1}{c}{ Variabel } & \multicolumn{1}{c}{ Sub-Variabel } \\
\hline Pemahaman mengenai BIM & 1. Mengetahui istilah BIM \\
& 2. Ketertarikan mengikuti BIM \\
& 3. BIM sebagai tren positif \\
& 4. Dampak positif BIM \\
5. Optimisme perkembangan BIM \\
\hline Manfaat BIM & 1. Produktivitas pekerjaan \\
& 2. Ramah lingkungan \\
& 3. Jadwal dan estimasi biaya akurat \\
& 4. Mempermudah proses perencanaan \\
& 5. Meminimalisir kesalahan perencanaan \\
& 6. Deteksi dini kesalahan \\
& 7. Mempermudah komunikasi \\
8. Meningkatkan kualitas konstruksi \\
\hline 1. Investasi biaya tinggi \\
2. Kurangnya pengetahuan \\
3. Enggan mempelajari teknologi baru \\
4. Minim dukungan perusahaan \\
5. Minim dukungan pemerintah \\
6. Minimnya fasilitas pelatihan BIM \\
\hline 1. Software legal BIM relatif mahal \\
2. Jaringan Internet cepat dan stabil \\
3. PC spesifikasi memadai untuk software \\
4. Bertambahnya biaya yang terjadi apabila \\
terjadi kegagalan \\
5. Biaya seminar dan pelatihan BIM \\
6. Implementasi BIM di pekerjaan \\
7. Mendukung perusahaan \\
8. Pergeseran budaya kerja \\
9. Mempelajari teknologi baru \\
10. Kesiapan dalam perkembangan teknologi \\
11. Kesiapan implementasikan BIM \\
\hline
\end{tabular}

Kuesioner didesain untuk mengetahui pemahaman konsultan perencana mengenai dasar-dasar BIM, pengaruh hambatan BIM, pengaruh manfaat BIM, dan tingkat kesiapan menghadapi berbagai tantangan adopsi BIM, juga terdapat beberapa pilihan jawaban mengenai proyek dan software BIM yang dapat dipilih sesuai dengan pengalaman kerja perusahaan konsultan perencana tersebut.

Rumus Slovin digunakan untuk penentuan sampel dengan taraf kesalahan 5\% atau tingkat kepercayaan 95\%. Dari 126 perusahaan konstruksi yang termasuk dalam klasifikasi kecil dan menengah didapatkan jumlah sampel seperti terlihat pada hasil berikut dengan $\mathrm{n}$ (jumlah sampel), $\mathrm{N}$ (jumlah populasi), dan e (tingkat kesalahan 5\%). 


$$
\begin{aligned}
n & =\frac{N}{1+N e^{2}} \\
n & =\frac{126}{1+126 \cdot(0.05)^{2}} \\
n & =95,817 \text { dibulatkan menjadi } 96
\end{aligned}
$$

Adapun sampel dari penelitian diambil berdasarkan data dari Ikatan Konsultan Indonesia (INKINDO) Palembang dengan klasifikasi kecil dan menengah. Dari data tersebut tidak terdapat perusahaan dengan klasifikasi besar yang terdaftar di Inkindo Palembang. Tabel 3 menyajikan perhitungan jumlah sampel untuk klasifikasi perusahaan menengah dan kecil.

Tabel 3 Sampel penelitian

\begin{tabular}{lccc}
\hline $\begin{array}{l}\text { Klasifikasi } \\
\text { Perusahaan }\end{array}$ & Populasi & Jumlah Sampel & Sampel \\
\hline Menengah & 15 & $(15 / 126) \times 96$ & 12 \\
\hline Kecil & 111 & $(15 / 126) \times 96$ & 84 \\
\hline Jumlah & & & 96 \\
\hline
\end{tabular}

Kuesioner disebar secara online melalui kontak perusahaan yang tertera dan juga dilakukan dengan mendatangi beberapa perusahaan secara langsung untuk diberikan link kuesioner maupun diberi kertas kuesioner secara langsung. Data yang didapat dari hasil kuesioner kemudian diolah menggunakan Microsoft excel dan SPSS ver 26. Data yang telah didapat dari pengisian kuesioner kemudian disajikan dalam bentuk tabel. Pengolahan data dilakukan dengan melakukan uji validitas dan reliabilitas dengan bantuan SPSS ver 26.

Uji validitas dilakukan untuk mengetahui valid atau tidaknya suatu data dari penelitian. Data dikatakan valid jika variabel tersebut dapat digunakan sesuai dengan tujuan pengukuran itu sendiri (Sugiyono, 2012).

Pengujian validitas dilakukan dengan menghitung Corrected Item Total Correlation ( $\mathrm{r}$ hitung) dengan rumus sebagai berikut:

$$
r=\frac{n(\Sigma x y)-(\Sigma x)(\Sigma y)}{\sqrt{\left\{n(\Sigma x)^{2}-(\Sigma x)^{2}\right\}\left\{n(\Sigma y)^{2}-(\Sigma y)^{2}\right\}}}
$$

di mana:

$$
\begin{aligned}
& \mathrm{r}=\text { koefisien korelasi } \\
& \mathrm{n}=\text { jumlah responden } \\
& \mathrm{x}=\text { skor tiap variabel } \\
& \mathrm{y}=\text { skor total tiap responden }
\end{aligned}
$$

Uji reliabilitas dilakukan untuk mengetahui tingkat konsistensi jawaban responden terhadap masing-masing butir variabel (Herlina, 2019). Untuk uji reliabilitas digunakan perhitungan Cronbach alpha dengan rumus sebagai berikut:

di mana:

$$
\mathrm{m}=\left(\frac{k}{k-1}\right)\left(1-\frac{\Sigma a b^{2}}{\Sigma a t^{2}}\right)
$$

$\mathrm{m}=$ reliabilitas instrumen

$\mathrm{k} \quad=$ jumlah butir pertanyaan

$\Sigma a b^{2}=$ total varian butir

$\Sigma a t^{2}=$ total varian 
Adapun kriteria dari pengujian validitas adalah data dikatakan valid apabila hasil pengujian SPSS ( $r$ hitung) lebih besar dari $r$ tabel dengan tingkat kesalahan sebesar 5\%. Indikator valid tidaknya suatu pertanyaan dinyatakan apabila $r$ hitung mempunyai nilai positif (+) dan lebih besar dari $r$ tabel. Untuk kriteria uji reliabilitas adalah data dikatakan reliabel kuat apabila nilai Cronbach alpha $>0,60$.

Untuk perhitungan rata-rata dan peringkat data dari seluruh jawaban pada masing-masing sub-variabel dicari rata-rata nilai sub-variabel tersebut. Dari nilai rata-rata tersebut, sub-variabel diurutkan rankingnya berdasarkan indeks nilai tertinggi hingga terendah untuk dikaji lebih jauh indikator dan penyebab nilai variabel tersebut.

\section{Hasil dan Pembahasan}

\subsection{Karakteristik Konsultan Perencana}

Pada kuesioner diberi beberapa pilihan terkait dengan keadaan konsultan perencana responden saat pengisian kuesioner berlangsung. Karakteristik yang diberikan antara lain jenis kelamin, rentang umur, pendidikan terakhir, bidang pekerjaan, dan lama bekerja. Adapun hasil karakteristik responden pada penelitian ini dapat dilihat pada Tabel 4.

Tabel 4 Karakteristik responden

\begin{tabular}{cccc}
\hline Karakteristik Responden & Kategori & Jumlah & Persentase \\
\hline Jenis Kelamin & Pria & 84 & $88 \%$ \\
\hline Rentang Umur & Wanita & 12 & $12 \%$ \\
\hline & $<25$ tahun & 0 & $0 \%$ \\
\hline & $25-35$ tahun & 16 & $17 \%$ \\
\cline { 2 - 4 } & $35-50$ tahun & 60 & $62 \%$ \\
\hline Pendidikan Terakhir & $>50$ tahun & 20 & $21 \%$ \\
\hline & SMA & 1 & $1 \%$ \\
\cline { 2 - 4 } & D3/D4/S1 & 80 & $83 \%$ \\
\hline Bidang Pekerjaan & S2 & 15 & $16 \%$ \\
\hline & S3 & 0 & $0 \%$ \\
\cline { 2 - 4 } & Struktur & 48 & $50 \%$ \\
\cline { 2 - 4 } & Arsitektur & 42 & $44 \%$ \\
\hline Lama Bekerja & MEP & 1 & $1 \%$ \\
\hline & Biaya & 5 & $5 \%$ \\
\cline { 2 - 4 } & $<1$ tahun & 0 & $0 \%$ \\
\hline & $1-5$ tahun & 10 & $10 \%$ \\
\cline { 2 - 4 } & $6-10$ tahun & 40 & $42 \%$ \\
\cline { 2 - 4 } & $>10$ tahun & 46 & $48 \%$ \\
\hline
\end{tabular}

Jenis kelamin dominan responden adalah pria dengan persentase sebesar $88 \%$ dikarenakan profesi konsultan perencana yang mempunyai risiko tinggi umumnya dikerjakan oleh pria apalagi yang bagi konsultan perencana yang mengetahui karakterisitik perusahaan tersebut. Rentang umur dominan responden adalah 35-50 tahun dengan persentase sebesar 62\%. Usia ini adalah usia produktif dengan pengalaman kerja yang sudah cukup tinggi sehingga dapat memegang peranan sebagai individu yang mengetahui karakteristik perusahaan. 
Pendidikan terakhir responden yang dominan adalah D3/S1 dengan persentase sebesar $83 \%$. Pendidikan D3/S1 merupakan rentang Pendidikan yang tepat untuk memasuki dunia kerja dengan ilmu pengetahuan dan teori yang diketahui telah cukup tinggi. Tingkat pendidikan yang lebih tinggi seperti S2 dan S3 umumnya memilih profesi lainnya sehingga memiliki persentase yang rendah. Dari pilihan bidang pekerjaan profesi konsultan perencana yang diberikan, bidang struktur dan arsitektur memiliki persentase yang relatif tinggi dibanding bidang lainnya dengan persentase masing-masing sebesar 50\% dan $44 \%$. Untuk durasi kerja umumnya responden telah bekerja 6-10 tahun atau lebih. Adapun persentase untung rentang durasi kerja ini masing-masing sebesar $42 \%$ dan $48 \%$. Waktu kerja ini merupakan jangka waktu yang sudah cukup panjang dan konsultan perencana sudah memiliki pengalaman yang cukup sehingga bisa dipercaya sebagai individu yang telah mengetahui seluk beluk dan kiprah perusahaan tersebut.

\subsection{Uji Validitas dan Reliabilitas}

Pengujian dilakukan kepada 30 sub-variabel yang dijawab oleh responden. Dari seluruh data jawaban pada setiap sub-variabel yang diuji semuanya valid dan reliabel sehingga dapat digunakan dalam analisis data.

1. Nilai proyek

Nilai proyek yang kecil cenderung sulit untuk mengimplementasikan BIM sehingga diperlukan analisis terhadap pengalaman proyek yang pernah dikerjakan oleh responden. Persentase diambil dari jumlah responden yang pemilih terhadap jumlah total responden yaitu 96 orang. Adapun nilai proyek yang pernah dikerjakan oleh responden dirangkum dalam tabel 5.

Tabel 5 Nilai proyek

\begin{tabular}{ccc}
\hline Nilai Proyek & Jumlah pemilih & Persentase \\
\hline < 200 juta & 25 & $26,04 \%$ \\
\hline 200 juta - 500 juta & 49 & $51,04 \%$ \\
\hline 500 juta - 1 Milyar & 75 & $78,13 \%$ \\
\hline 1 Milyar - 5 Milyar & 52 & $54,17 \%$ \\
\hline$>$ 5 Milyar & 13 & $13,13 \%$ \\
\hline
\end{tabular}

Nilai proyek yang dikerjakan responden seperti tampak pada Tabel 4. dapat dikategorikan klasifikasi proyek menengah. Kompleksitas implementasi BIM tidak akan berjalan secara maksimal dengan proyek bernilai kecil. Hal ini karena beberapa pekerjaan pada proyek bernilai kecil masih bisa dikerjakan dengan cara konvensional.

\section{Jenis Proyek}

Jenis proyek berkaitan dengan software BIM dengan kegunaan yang berbeda pula. Diberikan pilihan beberapa jenis proyek yang pernah dikerjakan. Persentase diambil dari jumlah responden yang pemilih terhadap jumlah total responden yaitu 96 orang. Umumnya proyek yang pernah dikerjakan adalah bangunan gedung dengan memanfaatkan aplikasi yang berkaitan dengan desain seperti AutoCAD 3D, SketchUp, atau Autodesk Revit. Adapun rangkuman jawaban responden dapat dilihat pada Tabel 6. 
Tabel 6 Jenis proyek

\begin{tabular}{lcc}
\hline Jenis Proyek & Jumlah pemilih & Persentase \\
\hline Bangunan Gedung & 87 & $90,60 \%$ \\
\hline Jalan & 51 & $53,10 \%$ \\
\hline Bangunan Air & 9 & $9,40 \%$ \\
\hline Stadion & 8 & $8,30 \%$ \\
\hline Bandara & 7 & $7,30 \%$ \\
\hline Lainnya & 4 & $4,10 \%$ \\
\hline Pelabuhan & 0 & $0 \%$ \\
\hline
\end{tabular}

3. Tuntutan pemilik proyek

Implementasi BIM dalam suatu proyek tidak hanya berasal dari keinginan konsultan perencana saja. Pemilik proyek dengan nilai tinggi memiliki kecenderungan meminta pihak konsultan perencana untuk menggunakan BIM dalam pekerjaannya. Seperti dalam regulasi dari Kementerian PUPR untuk bangunan negara. Penggunaan BIM ini berguna dalam meningkatkan mutu proyek serta meminimalkan risiko pengerjaan ulang (rework) yang mungkin terjadi. Pengerjaan ulang pada suatu proyek bernilai besar berisiko menimbulkan penambahan biaya. Adapun jawaban responden terkait tuntutan pemilik proyek terhadap penggunaan BIM dapat dilihat pada Tabel 7.

Tabel 7 Tuntutan pemilik proyek

\begin{tabular}{ccc}
\hline Tuntutan pemilik proyek & Jumlah pemilih & Persentase \\
\hline Ada & 24 orang & $31 \%$ \\
\hline Tidak Ada & 72 orang & $69 \%$ \\
\hline
\end{tabular}

Hasil dari bagian ini tergantung kepada nilai proyek yang pernah dikerjakan responden. Proyek bernilai kecil dan menengah cenderung tidak mendapat tuntutan dari pemilik proyek terkait implementasi BIM dalam pekerjaan, karena nilai proyek yang dikerjakan masuk kategori menengah, maka tuntutan pemilik proyek terhadap implementasi BIM juga rendah. Jawaban responden dominan tidak mendapat tuntutan dari pemilik proyek. Tuntutan dari proyek besar umumnya dari pihak pemerintah seperti proyek milik Kementerian PUPR.

\subsection{Variabel Pemahaman Dasar Mengenai BIM}

Tabel 8 menunjukkan peringkat pada variabel pemahaman dasar mengenai BIM. Peringkat pertama dengan kode P2 yaitu BIM sebagai tren positif di dunia konstruksi dengan nilai rata-rata 4,479. Nilai ini menggambarkan responden menyadari dengan sangat baik bahwa BIM merupakan tren dunia konstruksi yang positif. Kesadaran mengenai tren positif BIM tercipta dikarenakan berbagai faktor seperti maraknya sosialisasi yang dilakukan pemerintah terkait BIM serta seminarseminar mengenai aplikasi BIM yang banyak disebar pihak terkait. Peringkat kedua adalah kode P5 yaitu tingkat kepentingan software BIM dengan nilai rata-rata 4,458. Tingginya nilai rata-rata sub-variabel dikarenakan konsultan perencana yang menggunakan banyak software pada pekerjaannya baik software BIM maupun bukan. Penggunaan software ini membuat konsultan perencana sebagai responden menyetujui tingkat kepentingan software ini. Adapun penggunaan software BIM ini umumnya hanya digunakan terpisah pada bidang-biang pekerjaan sehingga belum termaksimalisasi penggunaannya secara integrasi antar jenis pekerjaan. 
Tabel 8 Variabel pemahaman dasar mengenai BIM

\begin{tabular}{cclc}
\hline Ranking & Kode & \multicolumn{1}{c}{ Pemahaman } & Rata-rata \\
\hline 1 & P2 & $\begin{array}{l}\text { BIM sebagai tren positif dunia } \\
\text { konstruksi }\end{array}$ & 4,479 \\
\hline 2 & P5 & $\begin{array}{l}\text { Software BIM penting diaplikasikan } \\
\text { pada pekerjaan }\end{array}$ & 4,458 \\
\hline 3 & P1 & $\begin{array}{l}\text { Ketertarikan mengikuti } \\
\text { perkembangan BIM di Indonesia }\end{array}$ & 4,344 \\
\hline 4 & P3 & $\begin{array}{l}\text { Adopsi BIM memberi berbagai } \\
\text { dampak positif }\end{array}$ & 4,292 \\
\hline 5 & P4 & $\begin{array}{l}\text { Optimisme peningkatan penggunaan } \\
\text { teknologi BIM }\end{array}$ & 3,771 \\
\hline \multicolumn{4}{c}{ Rata-rata skor variabel } \\
\hline
\end{tabular}

Peringkat 3 pada variabel ini adalah kode P1 yaitu ketertarikan mengikuti BIM dengan nilai rata-rata sebesar 4,344 yang menjelaskan bahwa responden memiliki minat dan ketertarikan yang cukup tinggi terhadap perkembangan BIM saat ini. Hal ini bisa disebabkan karena banyaknya sosialisasi dan seminar mengenai BIM saat ini. Nilai rata-rata skor variabel ini secara keseluruhan adalah 4,269 dan dapat dikatakan konsultan perencana yang mengisi kuesioner telah memahami dengan baik dasar-dasar mengenai BIM.

\subsection{Variabel Manfaat BIM}

Variabel ini memberi beberapa manfaat adopsi BIM terhadap pekerjaan konsultan perencana. Setelah dicari nilai rata-rata dan diurutkan berdasarkan peringkat tertinggi didapat sub-variabel M1 dengan nilai rata-rata sebesar 4,563. Adapun M1 merupakan manfaat BIM meningkatkan produktivitas. Konsultan perencana yang menjadi responden sangat setuju dengan manfaat ini. Dengan efisiensi waktu dan berbagai kemudahan dalam perencanaan, produktivitas konsultan perencana akan meningkat dengan digunakannya BIM apabila diaplikasikan dengan baik pada pekerjaan. Variabel selanjutnya dengan nilai ratarata tinggi adalah M8 yaitu meningkatkan kualitas desain dengan nilai rata-rata sebesar 4,365. Basis teknologi 3D pada BIM akan memudahkan dalam perencanaan maupun mendeteksi kesalahan perencanaan saat pekerjaan di lapangan dilakukan, dengan begitu kualitas desain akan bagus dan membuat bangunan lebih awet dan rapi.

Tabel 9 Variabel manfaat BIM

\begin{tabular}{cclc}
\hline Ranking & Kode & \multicolumn{1}{c}{ Manfaat BIM } & Mean \\
\hline 1 & M1 & Menambah produktivitas pekerjaan & 4,563 \\
\hline 2 & M8 & Meningkatkan kualitas desain & 4,365 \\
\hline 3 & M3 & Perkiraan jadwal dan biaya lebih akurat & 4,313 \\
\hline 4 & M4 & Mempermudah proses desain & 4,302 \\
\hline 5 & M5 & Meminimalisir kesalahan desain & 4,271 \\
\hline 6 & M7 & Komunikasi menjadi lebih mudah & 4,229 \\
\hline 7 & M6 & Kesalahan dapat diketahui lebih cepat & 4,219 \\
\hline 8 & M2 & $\begin{array}{l}\text { Ramah lingkungan dengan meminimalisir } \\
\text { penggunaan kertas }\end{array}$ & 3,989 \\
\hline & Rata-rata & 4,281 \\
\hline
\end{tabular}


Adapun manfaat dengan rata-rata tertinggi berikutnya adalah M3 yaitu penjadwalan dan estimasi biaya yang lebih akurat dengan nilai rata-rata sebesar 4,313. M3 akan sangat berguna dalam jangka panjang proyek berlangsung dan mampu mencegah konflik ketidaksesuaian antara pihak owner dengan kontraktor pelaksana. Adapun manfaat yang mendapat nilai mean terendah adalah M2 yaitu ramah lingkungan yaitu 3,989 hal ini disebabkan penggunaan kertas yang masih sangat diperlukan dalam pengerjaan konstruksi di Indonesia, sedangkan nilai ratarata variabel ini secara keseluruhan adalah 4,281 dengan klasifikasi "Setuju" sehingga dapat dikatakan konsultan perencana yang menjadi responden telah mengetahui pengaruh berbagai manfaat BIM pada proses pekerjaan perencanaan. Adapun manfaat yang diberikan merupakan beberapa manfaat BIM dari berbagai sumber dan penelitian sebelumnya yang telah dirangkum sedemikian rupa.

\subsection{Variabel Hambatan Adopsi BIM}

Hambatan utama dalam mengadopsi BIM berdasarkan Tabel 9 adalah investasi biaya awal yang tinggi. Perusahaan cenderung tidak menyiapkan dana yang besar di awal proyek dan pesimis dana yang dikeluarkan di awal tidak balik lagi. Investasi biaya ini meliputi biaya software, PC, tenaga kerja profesional, dan pembelajaran bagi pekerja yang belum mengerti. Hambatan lainnya adalah cenderung nyaman dengan budaya kerja yang lama. Kenyamanan ini menimbulkan keengganan untuk mengikuti perkembangan teknologi dan mempelajarinya, hal ini terutama terjadi pada pekerja yang sudah cukup berumur.

Tabel 10 Variabel hambatan adopsi BIM

\begin{tabular}{cclc}
\hline Ranking & Kode & \multicolumn{1}{c}{ Hambatan Adopsi BIM } & Rata-rata \\
\hline 1 & H1 & Investasi awal relatif besar & 4,688 \\
\hline 2 & H3 & $\begin{array}{l}\text { Sudah nyaman dengan metode kerja } \\
\text { yang lama }\end{array}$ & 4,281 \\
\hline 3 & H2 & Minim pengetahuan tentang BIM & 4,198 \\
\hline 4 & H5 & Minim dukungan dari pemerintah & 4,156 \\
\hline 5 & H6 & $\begin{array}{l}\text { Minimnya fasilitas seminar dan } \\
\text { training untuk mempelajari BIM }\end{array}$ & 4,01 \\
\hline 6 & H4 & Minimnya dukungan pihak perusahaan & 3,885 \\
\hline & & Rata-rata & 4,203 \\
\hline
\end{tabular}

Hambatan lainnya adalah kurangnya pengetahuan mengenai BIM. Keengganan untuk mengikuti perkembangan teknologi mengakibatkan pengetahuan dan informasi yang terbatas mengenai BIM. Kurangnya pengetahuan diakibatkan minimnya akses menuju informasi atau tidak adanya keinginan dari sumber daya manusia. Secara keseluruhan rata-rata variabel ini adalah 4,203 yang menunjukkan responden menganggap berbagai hambatan yang diberikan pada pilihan berpengaruh terhadap tingkat adopsi BIM. Selain itu, biaya peralihan penggunaan BIM dan keengganan untuk mempelajari teknologi baru karena sudah nyaman dengan sistem konvensional juga menjadi faktor penghambat utama dalam mengadopsi BIM (Mieslenna and Wibowo, 2019).

\subsection{Variabel kesiapan menghadapi hambatan adopsi BIM}

Dari berbagai hambatan pada variabel sebelumnya, dirangkum tingkat kesiapan konsultan perencana dalam menghadapi variabel-variabel tersebut. 
Adapun hambatan yang mendapat nilai rata-rata terendah berkaitan dengan biaya adopsi yang mahal. Seperti T1 yaitu harga software yang mahal, PC spesifikasi tinggi untuk mendukung penggunaan BIM, Penambahan biaya yang terjadi, biaya seminar dan pelatihan, dan kecepatan internet. Konsultan perencana cenderung menjawab tidak siap untuk hal yang berkaitan dengan uang, hal ini disebabkan perusahaan yang memang mencari laba dari setiap proyek serta ketiadaan investor yang bersedia memberi dana. Sementara hal-hal yang berkaitan dengan kesiapan psikologi mendapat rata-rata yang cukup walaupun tidak tinggi seperti dukungan kepada perusahaan dan menghadapi perkembangan teknologi.

Tabel 11 Kesiapan menghadapi hambatan adopsi BIM

\begin{tabular}{cclc}
\hline Ranking & Kode & \multicolumn{1}{c}{ Hambatan Adopsi BIM } & $\begin{array}{c}\text { Rata- } \\
\text { rata }\end{array}$ \\
\hline 1 & T7 & Dukungan kepada perusahaan & 3,833 \\
\hline 2 & T10 & Perkembangan pesat teknologi & 3,719 \\
\hline 2 & T11 & $\begin{array}{l}\text { Implementasi BIM untuk menikuti regulasi } \\
\text { pemerintah }\end{array}$ & 3,719 \\
\hline 4 & T9 & Belajar teknologi baru & 3,667 \\
\hline 5 & T8 & Adaptasi terhadap budaya kerja berbasis BIM & 3,614 \\
\hline 6 & T6 & Kesiapan implementasi BIM & 3,573 \\
\hline 7 & T2 & Jaringan internet cepat dan stabil & 3,364 \\
\hline 8 & T5 & Biaya untuk pelatihan BIM & 2,510 \\
\hline 9 & T4 & Penambahan biaya proyek & 2,438 \\
\hline 10 & T3 & PC dengan spesifikasi tinggi & 2,396 \\
\hline 11 & T1 & Harga software legal yang cenderung mahal & 2,219 \\
\hline & & Rata-rata & $\mathbf{3 , 1 8 7}$ \\
\hline
\end{tabular}

\subsection{Potensi peningkatan implementasi BIM di masa depan}

Potensi peningkatan implementasi BIM di Indonesia khususnya di Kota Palembang dikaji dari beberapa sub-variabel pada penelitian ini. Misal pada P1 mengenai minat konsultan perencana terhadap BIM didapat nilai rata-rata sebesar 4.344 yang menjelaskan bahwa konsultan perencana memiliki respon yang cukup positif terhadap implementasi BIM di Indonesia. Hal ini juga akan menjadi salah satu faktor penentu dalam meningkatkan implementasi BIM.

Tingkat optimisme pada P4 didapat hasil nilai rata-rata 3,771 yang menunjukkan variasi tingkat optimisme konsultan perencana yang menjadi responden. Terjadi pro dan kontra terhadap P4 namun masih menunjukkan nilai rata-rata yang cukup tinggi yang berarti konsultan perencana di Kota Palembang cukup optimis terhadap peningkatan adopsi BIM di masa depan.

Dari variabel $\mathrm{T}$ di mana terdapat 11 sub-variabel didapatkan nilai rata-rata 3,187 merupakan tingkatan menengah yang berarti cukup siap untuk menimplemetasikan BIM dalam mengkaji kesiapan konsultan perencana. Tingkat kesiapan ini akan sangat berpengaruh untuk meningkatkan implementasi BIM di masa depan. Dari ketiga kajian tersebut dapat dikatakan potensi implementasi BIM di Kota Palembang berpeluang mengalami peningkatan namun tidak dengan proses yang instan dan membutuhkan waktu secara berkala. Peranan kesadaran perusahaan dan individu di dalamnya serta ketegasan pemerintah akan menentukan tingkat perkembangan ini. 


\section{Kesimpulan dan Saran}

\subsection{Kesimpulan}

Berdasarkan hasil analisis dapat disimpulkan bahwa tingkat kesiapan konsultan perencana di Kota Palembang dalam mengadopsi BIM di era industri 4.0 berada dalam kategori cukup siap yang ditunjukkan dengan nilai rata-rata sebesar 3,187. Tingkat kesiapan ini akan sangat berpengaruh untuk meningkatkan implementasi BIM di masa depan. Dapat juga disimpulkan bahwa potensi implementasi BIM di Kota Palembang berpeluang mengalami peningkatan namun tidak dengan proses yang instan dan membutuhkan waktu secara berkala. Peranan kesadaran perusahaan dan individu di dalamnya serta ketegasan pemerintah akan menentukan tingkat perkembangan ini. Selain itu, dari analisis yang dilakukan terhadap variabel pemahaman dasar mengenai BIM didapatkan skor rata-rata sebesar 4,269 yang berarti bahwa responden telah mengetahui dan memahami istilah-istilah dasar mengenai BIM walaupun aplikasi BIM pada pekerjaannya belum terkoordinasi dengan pekerjaan lainnya. Dari variabel manfaat adopsi BIM didapat skor rata-rata sebesar 4,281 juga menunjukkan bahwa responden mengetahui berbagai manfaat BIM yang diberikan dan menyadari manfaat BIM tersebut apabila diaplikasikan pada pekerjaan. Untuk variabel hambatan utama dalam mengadopsi BIM didapatkan yaitu investasi biaya awal yang tinggi, kenyamanan dengan budaya kerja saat ini, dan minimnya pengetahuan mengenai BIM. Perkiraan adopsi BIM di Kota Palembang akan meningkat secara perlahan dan dalam jangka waktu yang tidak sebentar. Peranan pemerintah dan perusahaan konsultan akan berperan besar dalam meningkatkan tingkat adopsi tersebut.

\subsection{Saran}

Penelitian ini terbatas hanya kepada konsultan perencana di Palembang saja dan sebaiknya dapat menjangkau pelaku industri konstruksi yang lebih luas lagi, dengan demikian hasil yang disajikan dapat memberikan pedoman dan kerangka kerja dalam upaya pengembangan industri konstruksi di Palembang khususnya dan Indonesia pada umumnya.

\section{Daftar Kepustakaan}

Agirachman, F. A., Putra, I. F. and Angkawijaya, A, 2018. Initial Study on Building Information Modeling Adoption Urgency for Architecture Engineering and Construction Industry in Indonesia. MATEC Web of Conferences, 147, pp. 0-5. doi: 10.1051/matecconf/201814706002.

Alwan, Z., Jones, P. and Holgate, P, 2017. Strategic sustainable development in the UK construction industry, through the framework for strategic sustainable development, using Building Information Modelling. Journal of Cleaner Production. Elsevier Ltd, 140, pp. 349-358. doi: 10.1016/j.jclepro.2015.12.085. 
BPS, 2019. No Title. 05340.2002. Available at: https://www.bps.go.id/publication/ 2020/04/30/0e1ea759aad0ffddff2ae8a7/indikator-konstruksi-triwulan-iv2019.html.

Dahlberg, T, 2016. The creation of inter-organisational IT governance fo social welfare and healthcare IT - Lessons from a case study. International Journal of Networking and Virtual Organisations, 16(1), pp. 38-71. doi: 10.1504/IJNVO.2016.075132.

Hatmoko, J. U. D. et al, 2019. Investigating Building Information Modelling (BIM) Adoption in Indonesia Construction Industry. MATEC Web of Conferences, 258, p. 02006. doi: 10.1051/matecconf/201925802006.

Herlina, V, 2019. Panduan Praktis Mengolah Data Kuesioner Menggunakan SPSS. PT. Elex Media Komputindo, Jakarta

Juan, Y. K., Lai, W. Y. and Shih, S. G, 2017. Building information modeling acceptance and readiness assessment in Taiwanese architectural firms. Journal of Civil Engineering and Management, 23(3), pp. 356-367. doi: 10.3846/13923730.2015.1128480.

Khosrowshahi, F. and Arayici, Y, 2012. Roadmap for implementation of BIM in the UK construction industry. Engineering, Construction and Architectural Management, 19(6), pp. 610-635. doi: 10.1108/09699981211277531.

Latiffi, A. A., Brahim, J. and Fathi, M. S, 2016. Transformation of Malaysian Construction Industry with Building Information Modelling (BIM). MATEC Web of Conferences, 66. doi: 10.1051/matecconf/20166600022.

Liao, L. and Teo, E. A. L, 2019. Managing critical drivers for building information modelling implementation in the Singapore construction industry: an organizational change perspective. International Journal of Construction Management. Taylor \& Francis, 19(3), pp. 240-256. doi: 10.1080/15623599.2017.1423165.

LPJK, 2015. Indonesia Pasar Konstruksi Terbesar di Asia Tenggara. Available at: https://lpjk.pu.go.id/?p=1282.

Mieslenna, C. F. and Wibowo, A, 2019. Mengeksplorasi Penerapan Building Information Modeling (BIM) Pada Industri Konstruksi Indonesia Dari Perspektif Pengguna. Jurnal Sosial Ekonomi Pekerjaan Umum, pp. 44-58.

PUPR, K, 2018. Peraturan Menteri Nomor 22/PRT/M/2018, Jaringan Dokumentasi dan Informasi Hukum. Available at: https://jdih.pu.go.id/detaildokumen/2594/1.

Simanjuntak, M. R. A. and Herriza, A, 2019. Studi Peran Konsultan Perencana Bangunan Gedung Monumental Masjid Raya Provinsi Jawa Barat Pada Tahap Pelaksanaan Konstruksi. in Prosiding Seminar Nasional Teknik Sipil. Fakultas Teknik Universitas Muhammadiyah Surakarta, pp. 273-278.

Smith, P, 2014. BIM implementation - Global strategies. Procedia Engineering, 85, pp. 482-492. doi: 10.1016/j.proeng.2014.10.575.

Sugiyono, 2012. Memahami Penelitian Kualitatif. Alfabeta, Bandung 
Telaga, A. S, 2018. A review of BIM (Building Information Modeling) implementation in Indonesia construction industry. IOP Conference Series: Materials Science and Engineering, 352(1). doi: 10.1088/1757899X/352/1/012030.

Utomo, F. R. and Rohman, M. A, 2019. The Barrier and Driver Factors of Building Information Modelling (BIM) Adoption in Indonesia: A Preliminary Survey. IPTEK Journal of Proceedings Series, 0(5), p. 133 . doi: 10.12962/j23546026.y2019i5.6291.

Wang, X, 2012. BIM Handbook: A guide to Building Information Modeling for owners, managers, designers, engineers and contractors, Construction Economics and Building. doi: 10.5130/ajceb.v12i3.2749.

Wong, A. K. D., Wong, F. K. W. and Nadeem, A, 2010. Attributes of building information modelling implementations in various countries. Architectural Engineering and Design Management, 6(SPECIAL ISSUE), pp. 288-302. doi: 10.3763/aedm.2010.IDDS6. 